\title{
THE DOMESTIC GENERIC
}

\section{BRIT TANY UT TING}

Fellow, Taubman College of

Architecture + Urban Planning,

University of Michigan, USA

\section{Keywords}

Freedom

City

Design

Research

Housing
Although the real estate catalog supposedly promotes freedom of choice, in practice it reduces it by converting it into a mere combinatorial system between predefined options that, in turn, suppose standard life forms. Taking advantage of the typological indifference of the real estate catalog, this proposal uses the same tool - the catalog - to emancipate the subjectivities instead of reproducing them. Thus, architecture could help to recover that freedom of choice that today is only illusory.

\footnotetext{
$T$
} he developer's catalog of homes is perhaps the most prolific author of the suburban landscape. This list of houses-as-products constructs an ideologically and aesthetically monitored supply chain, offering an inventory and ethos to its customers. The database of houses - a combinatorics of styles and types - constitutes a logistical system of material distribution and behavioral management that structures suburban inhabitation. As a series of drawings, images, financial analyses, and slogans, these catalogs co-opt the narratives of the home to support an economy that relies on the "continual proliferation of masquerades and fictions" (Easterling, 2005). If instead we misuse the indifference of the catalog, instrumentalizing its incongruity between space and image, what freedoms could a new domestic generic offer? How can we emancipate the specificity of the developer's plan to create a more open architectural framework, one that can reconstruct our collective life, leisure, and labor?

The catalog of homes typically describes each model through a stylistic narrative coupled with a 


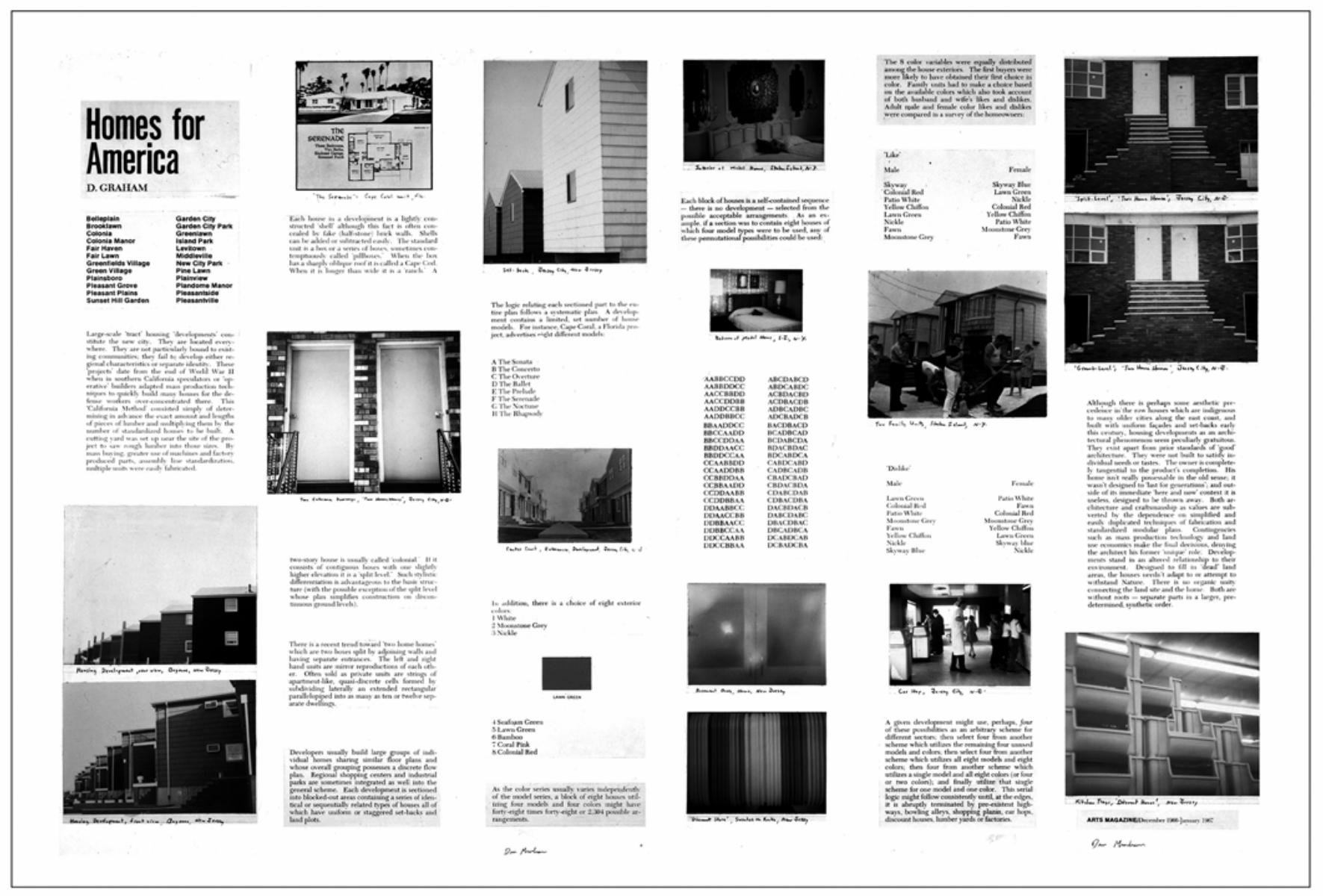

The logic relating each sectioned part to the entire plan follows a systematic plan. A development contains a limited, set number of house models. For instance, Cape Coral, a Florida project, advertises eight different models:

A The Sonata

B The Concerto

C The Overture

D The Ballet

E The Prelude

F The Serenade

G The Noctune

$\mathrm{H}$ The Rhapsody

FIG 1 Dan Graham. "Homes for America". Arts Magazine 41, 3 (1966-1967). Cortesía de / Courtesy of the Dan Graham and Marian Goodman Gallery, Paris. 
$N^{\circ} 006$
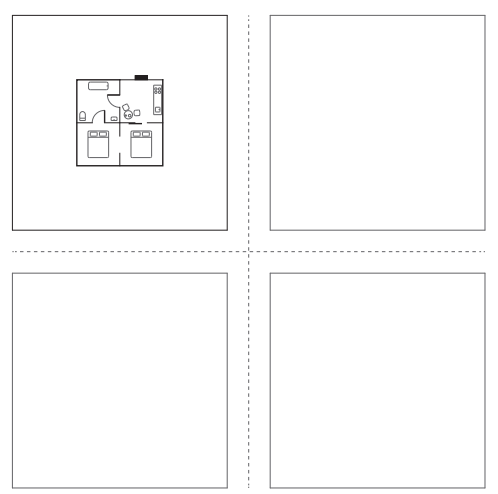

$N^{\circ} 045$

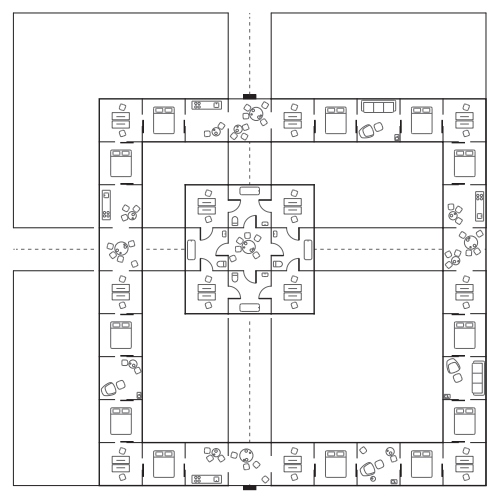

$\mathrm{N}^{\circ} 117$
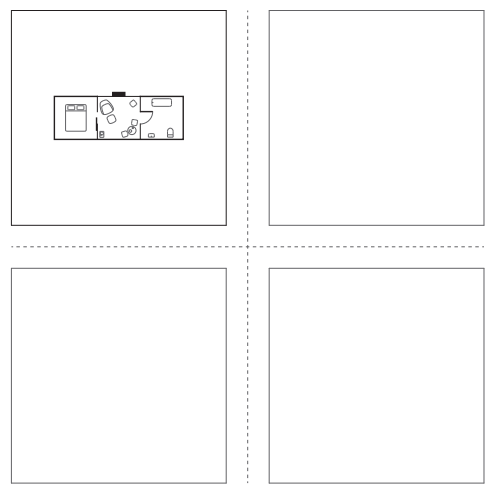

$\mathrm{N}^{\circ} 010$
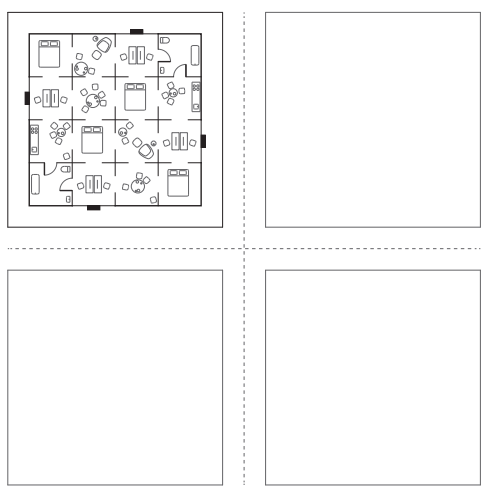

$\mathrm{N}^{\circ} 047$
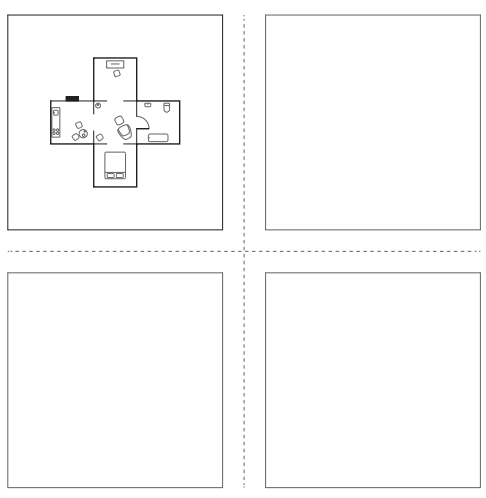

$\mathrm{N}^{\circ} 138$
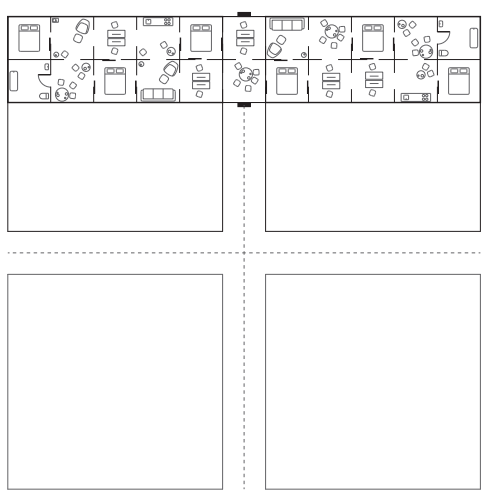

FIG 2 Casas Modelo /

Model Homes N. 006, o10,

045, 047, 117, 138.

(C) Brittany Utting floor plan. Each model's name is meant to appeal to a consumer archetype, attaching a standard plan to a standardized subject by anticipating their taste, decorum, and desire. In the popular Sears Homes of the 1930s, designations such as "The Cape Cod N" 13354A, 13354B," "The Chateau N³378," and "The Milford $\mathrm{N}^{\circ} 3385$ " symbolically align each model with an associated architectural style. The tone is indulgently nostalgic, but at odds with the numerical designation of each model. The Cape Cod advertisement touts the "certain softness and lasting character in this New England type" (Sears, Roebuck, and Co., 1934) while The Milford paternalistically reminds the buyer: "Men are judged largely by the home they live in. 
A home like the Milford is a credit to you, your family and every neighborhood" (Sears, Roebuck, and Co., 1935). Although these architectural brands position each model with a particular ethos, the jarring label " $\mathrm{N}^{\circ} 13354 \mathrm{~A}, 13354 \mathrm{~B}$ " tells a parallel story. The pragmatism of the alphanumerical index reveals the underlying contentlessness of its architectural image: each floor plan is a single instantiation of an extensive series completely disassociated from its branded historical style. If we are to dismantle these domestic mythologies to suggest new forms of political, territorial, and material life, why not through a re-appropriation of the home's ultimate indifference to its subjects?

The catalog's combinatorics of architectural style and model number leverages the iconography of the home to clad otherwise standardized floor plans. This coordinated management of aesthetic and stylistic variety with an otherwise homogeneous building stock is most clearly critiqued in Dan Graham's 1966-1967 "Homes for America" (FIG.1). He begins by listing the available styles and colors in a set of developer tract houses in Cape Coral, Florida: "A The Sonata, B The Concerto, C The Overture... [and] 1 White, 2 Moonstone Grey, 3 Nickel, 4 Seafoam Green" (Graham, 1966:67). Graham proceeds to calculate all possible combinations of houses for a block: "a block of eight houses utilizing four models and four colors might have forty-eight times forty-eight or 2,304 possible arrangements" (Graham, 1966:67). The doggedness of his computational method and the exhaustiveness of the catalog reconstructs the "useless machine" (Tafuri, 1976:15) of suburban development. If the mass deployment of the home can restructure a territory, what new freedoms of urban form and domestic deployment are possible in these combinatorial games? If the suburb continues to constitute a space of ex-urban desires despite increasing post-crisis precarity, how do designers operate parallel to the housing market with renewed socio-political instrumentality, using the home to produce alternatives to market-ready forms of valorization?

By co-opting these regimes of domestic production, architects can decouple the home from the flows of wealth, debt, efficiency analytics, and market-driven data that manage the suburb to operate instead as a proxy for new models of cohabitation, consumption, and production. The 138 Model Homes project ${ }^{1}$ appropriates the suburban paradigms of deadpan combinatorics, material distribution, and organizational logistics employed by Levittown and the Sears catalog to disrupt the expediencies of capitalism, proposing alternative ecologies of occupancy and use. By instrumentalizing the combinatorial irreverence of the catalog, these 138 Model Homes seek to heighten the contradictions and extremes of the suburban enclave. Embracing the indifference of the typical, 


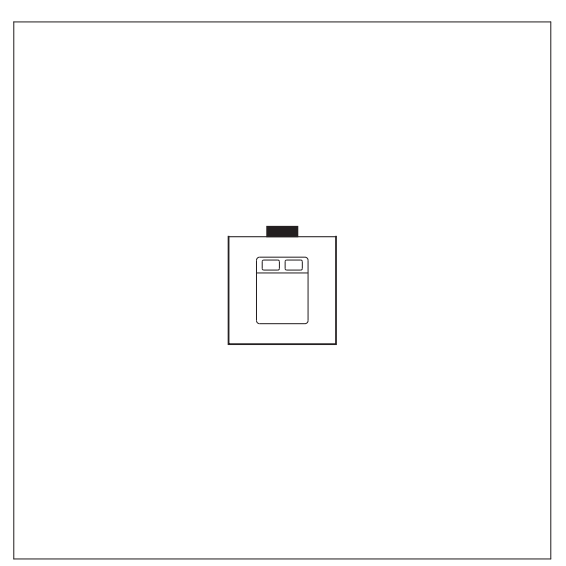

Conteo de habitaciones / Room count

001 Habitación(es) para dormir / Room(s) to sleep

000 Habitación(es) para bañarse / Room(s) to bathe

000 Habitación(es) para trabajar / Room(s) to work

000 Habitación(es) para jugar / Room(s) to play

000 Habitación(es) para cocinar / Room(s) to cook

000 Habitación(es) para comer / Room(s) to eat

001 Total de habitación(es) / Total room(s)

001 Habitación(es) perimetral(es) / Perimeter room(s)

100 Privado / Private

000 Público / Public

Nodos de acceso / Access nodes

001 Entrada exterior / Exterior entry

000 Puerta(s) interior(es) / Interior door(s)

000 Corredor(es) / Corridor(s)

Datos de zonificación / Zoning data

000 Constructibilidad / Far

100 Porcentaje dentro del terreno / Percentage on lot

000 Porcentaje de servidumbre / Percentage on easement

Superficie / Square footage

Casa / House

$9 \mathrm{~m}^{2}$

Terreno / Lot

$930 \mathrm{~m}^{2}$

FIG 3 Casa Modelo $\mathrm{N}^{\circ}$ ool: La casa con una sola cama. / Model Home ${ }^{\circ}$ oor: The House with Only a Bed.

(C) Brittany Utting the project abstracts the home into a series of rooms, producing a generic diagram already supported by the softwares of the developer (FIG.2). By simplifying the organizational diagram of the home into the most basic conditions of daily life - eating, sleeping, bathing, working, relaxing - there is the possibility of reprogramming the home to produce radically new forms of domesticity. These planimetric permutations belong to a new catalog of domestic models characterized by minimalisms and excesses (FIG.3), exotic layouts, programmatic duplications, and spatial redundancies that resist the homogeneity expected from typical homes.

While the home has historically produced an ethos about socio-political status, family, hygiene, privacy, gender, ownership, and even morality, it could alternatively perform as a generic frame upon which the social, political, and economic conventions of domestic space are re-inscribed. By reducing the home to a series of rooms specified by furnishings and 


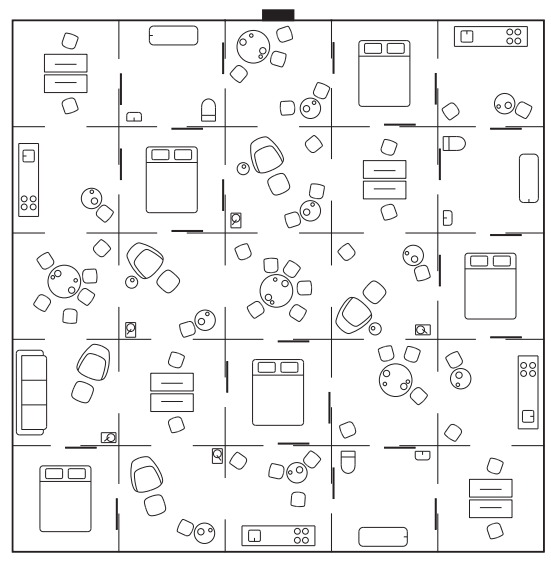

Conteo de habitaciones / Room count

005 Habitación(es) para dormir / Room(s) to sleep

003 Habitación(es) para bañarse / Room(s) to bathe

003 Habitación(es) para trabajar / Room(s) to work

005 Habitación(es) para jugar / Room(s) to play

004 Habitación(es) para cocinar / Room(s) to cook

004 Habitación(es) para comer / Room(s) to eat

025 Total de habitación(es) / Total room(s)

016 Habitación(es) perimetral(es) / Perimeter room(s)

032 Privado / Private

068 Público / Public

Nodos de acceso / Access nodes

001 Entrada exterior / Exterior entry

023 Puerta(s) interior(es) / Interior door(s)

000 Corredor(es) / Corridor(s)

Datos de zonificación / Zoning data

001 Constructibilidad / Far

100 Porcentaje dentro del terreno / Percentage on lot

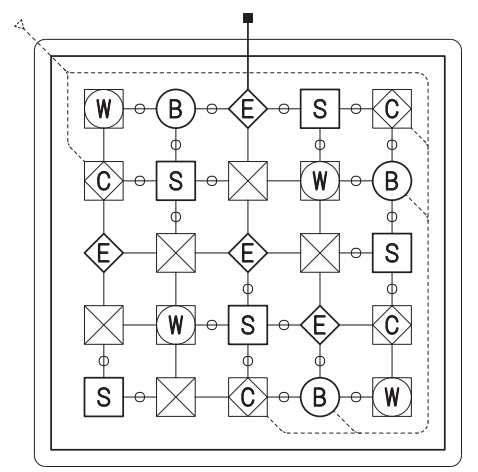

000 Porcentaje de servidumbre / Percentage on easement

Superficie / Square footage

Casa / House

$357 \mathrm{~m}^{2}$

Terreno / Lot

$930 \mathrm{~m}^{2}$

fixtures, the abstraction of the diagram allows us to decouple the home from its persuasive aesthetics, stylized regimes, and instructional iconographies. The typological indifference to style allows the home's narratives and slogans to accommodate new modes of cohabitation, producing more freedom for self-determination through an unconventional set of spatial relationships (FIG.4). For instance, how can the simple elimination of the hallway undermine the maintenance of privacy? How does the removal of the private kitchen from the home open up spaces for collective use and negotiation? How do the multiplication and redundancies of spaces for leisure or labor create new patterns of occupancy, use, and commerce within the home? How can the occupation and the sharing of boundaries challenge conditions of property, access, stewardship, and consensus? If we minimize domestic infrastructures, can people begin to leverage the costs of ownership to decrease the
FIG 4 Casa Modelo $\mathrm{N}^{\circ}$ 023: La casa sin estructuras de parentesco. / Model Home $N^{\circ}$ O23: The House without Kindship Structures. (c) Brittany Utting 
FIG 5 Catálogo:

138 casas modelo:

1674 habitaciones,

326 baños. / Catalog

Inventory: 138 Model

Homes: 1674 Rooms, 326

Toilets.

(c) Brittany Utting

138 casas modelo: 1674 habitaciones / 138 model homes: 1674 rooms

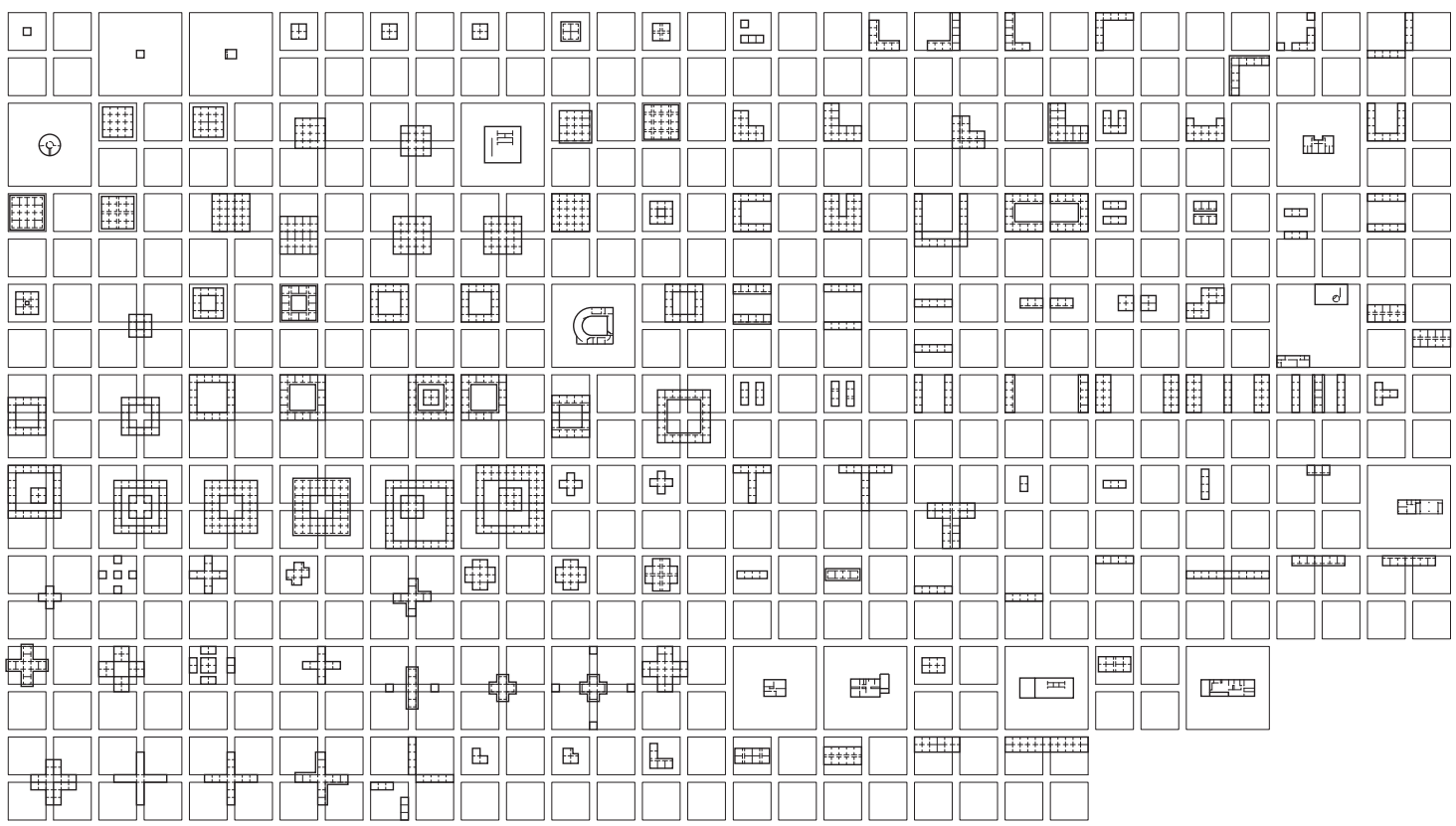

138 casas modelo: 326 baños / 138 model homes: 326 toilets

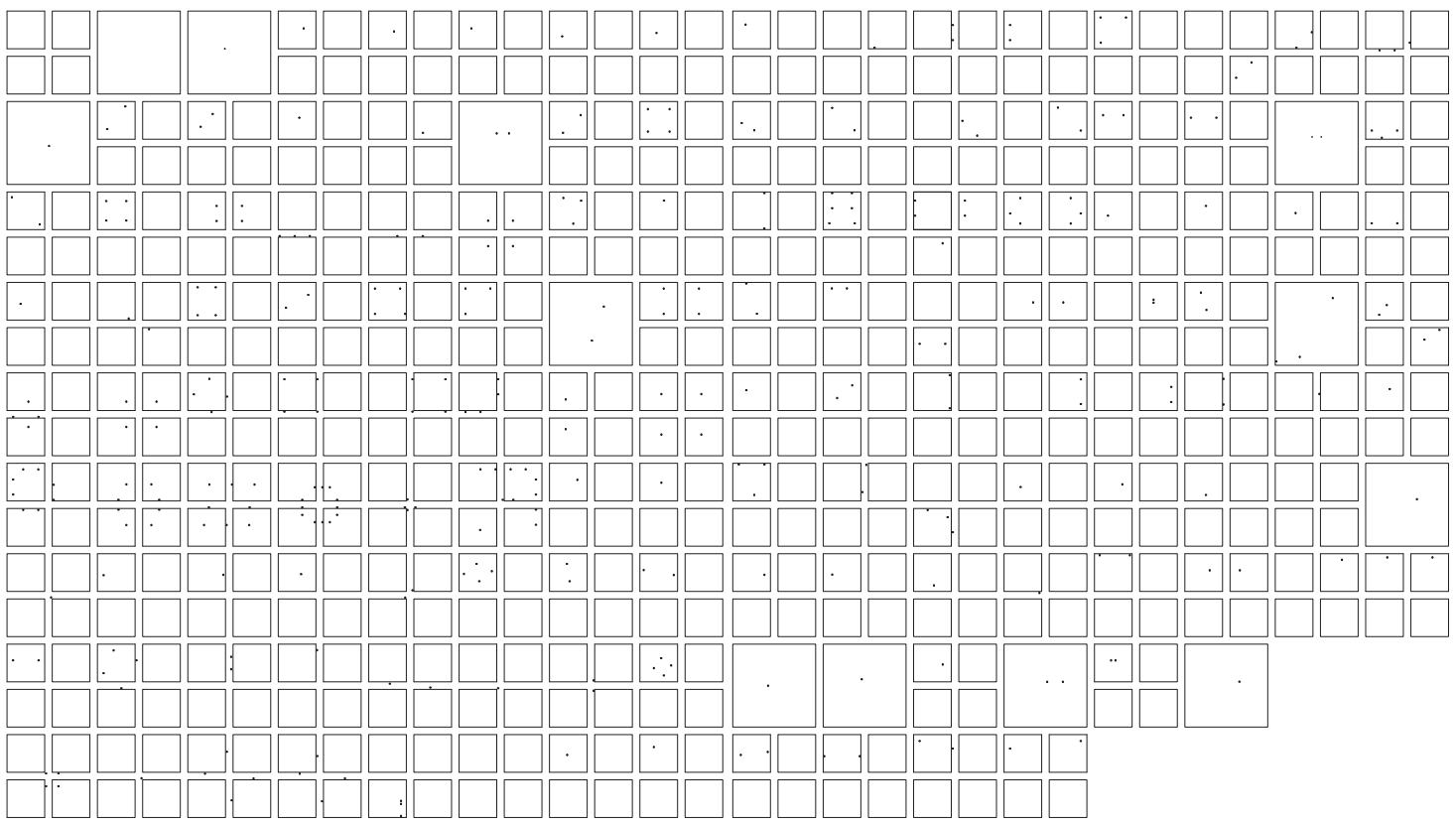


financial risks and increase the financial opportunities of the home?

The plan governs as both a topological framework and a data set. This new catalog of homes acknowledges the metrics of real estate value and cost, instrumentalizing dimensions, inventories, appliance redundancies, net-to-gross square footages, floor-toarea ratios, and municipal utility availability. However, by playing the same game of quanta and performance, we can begin to undermine the logic of the market by proposing an alternative set of values. While the inventories of appliances and rooms of the 138 Model Homes mimic the economic regimes of development by reducing the home to a density and distribution of toilets, refrigerators, and doorknobs (FIG.5), they simultaneously represent a different ecology of cohabitation and resource management that counter the norms of private consumption.

This catalog of model homes appropriates the generic framework of type to resist the market of lifestyle-as-image. Enacting the digital impulses of seriality, lists, and non-compositional grammars, 138 Model Homes is a catalog that is "fundamentally parsimonious and systematically self-exhausting" (Bochner, 1967:28). While seemingly reproducing the pathologies of the suburban catalog, the limitless combinatorial possibilities of domestic space, stripped to the barest spatial grammar, constitute a refusal to participate in the stylistic regimes of the home, creating domestic spaces devoid of ready-made content, image, and identity: a new collection of homes without quality.

Enacting architectural form as political form, 138 Model Homes is a set of housing types that emancipates rather than reproduces subjectivities. If the suburb persists as the dominant paradigm in housing today, can there be a more radical model for suburban space, one that leverages the open frame of the domestic generic to inscribe more varied forms of private and public life? Re-scripting the suburb's traditional role as an instrument of ideology and governance, 138 Model Homes constitutes the protocols for a new suburb (FIG.6). Characterized by typological excess and topological diversity, these unfamiliar re-arrangements of rooms produce housing types that question pre-determined and standardized kinship structures, making space for negotiation and bargaining, enacting alternative structures of use, ownership, and collectivity. The resulting layout's juxtaposition of types creates new confrontations, new courtyards and clearings, more obstructions but also more routes and itineraries. 
FIG 6 Posible vecindario suburbano formada por una selección de 100 casas de los 138 tipos posibles. / Possible suburban neighborhood composed of 100 homes selected from 138 possible types.

(c) Brittany Utting

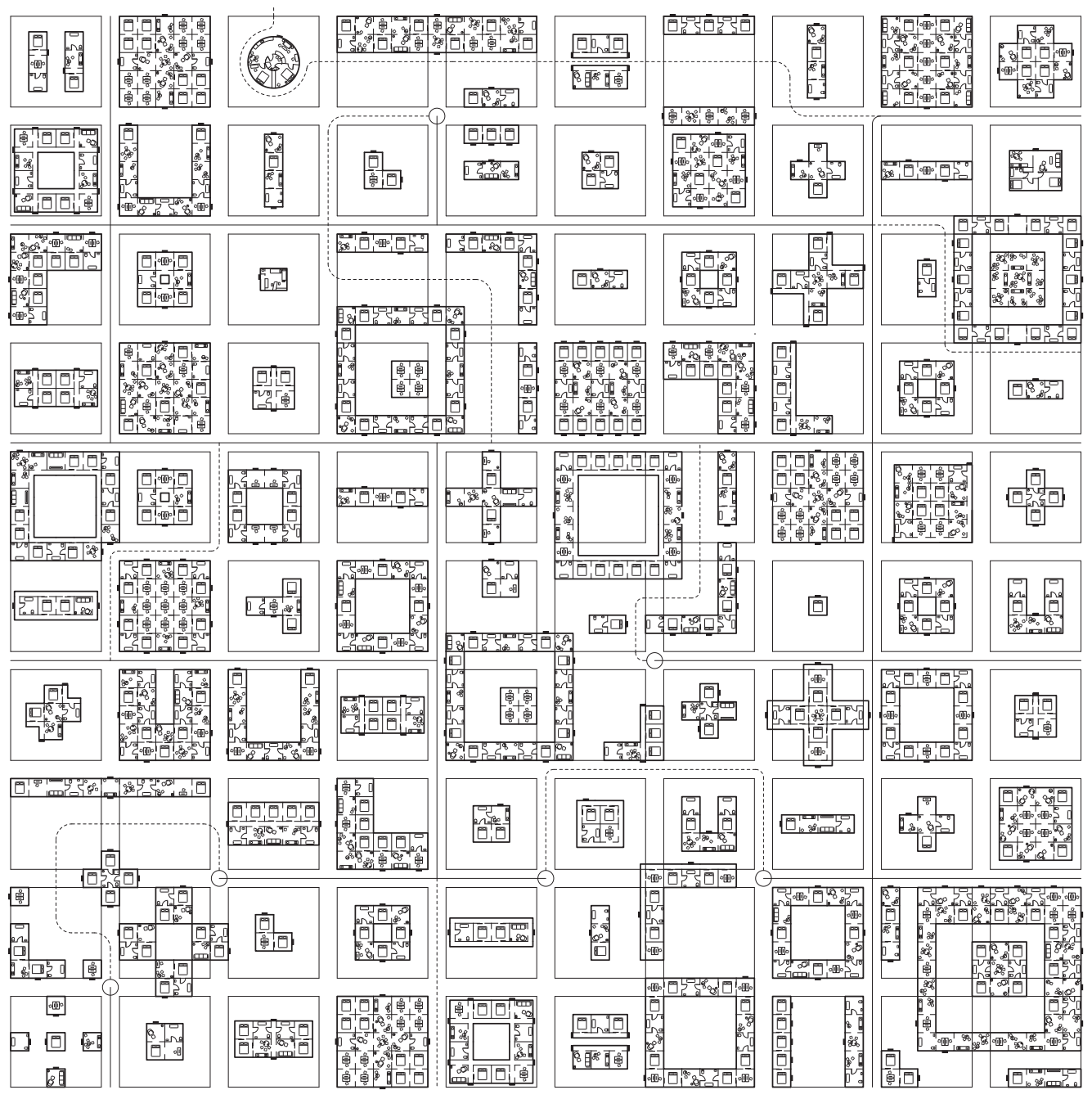

Operating as a spatial proxy for new practices of daily life and labor, these model homes offer alternative frameworks through which to restructure consumption, reproduction, and behavior. Rather than choosing from a catalog of signature homes with ready-made lifestyles, there is instead an alternative litany of housing types, embodying a new ethos for daily life. ARQ 
Listado / List

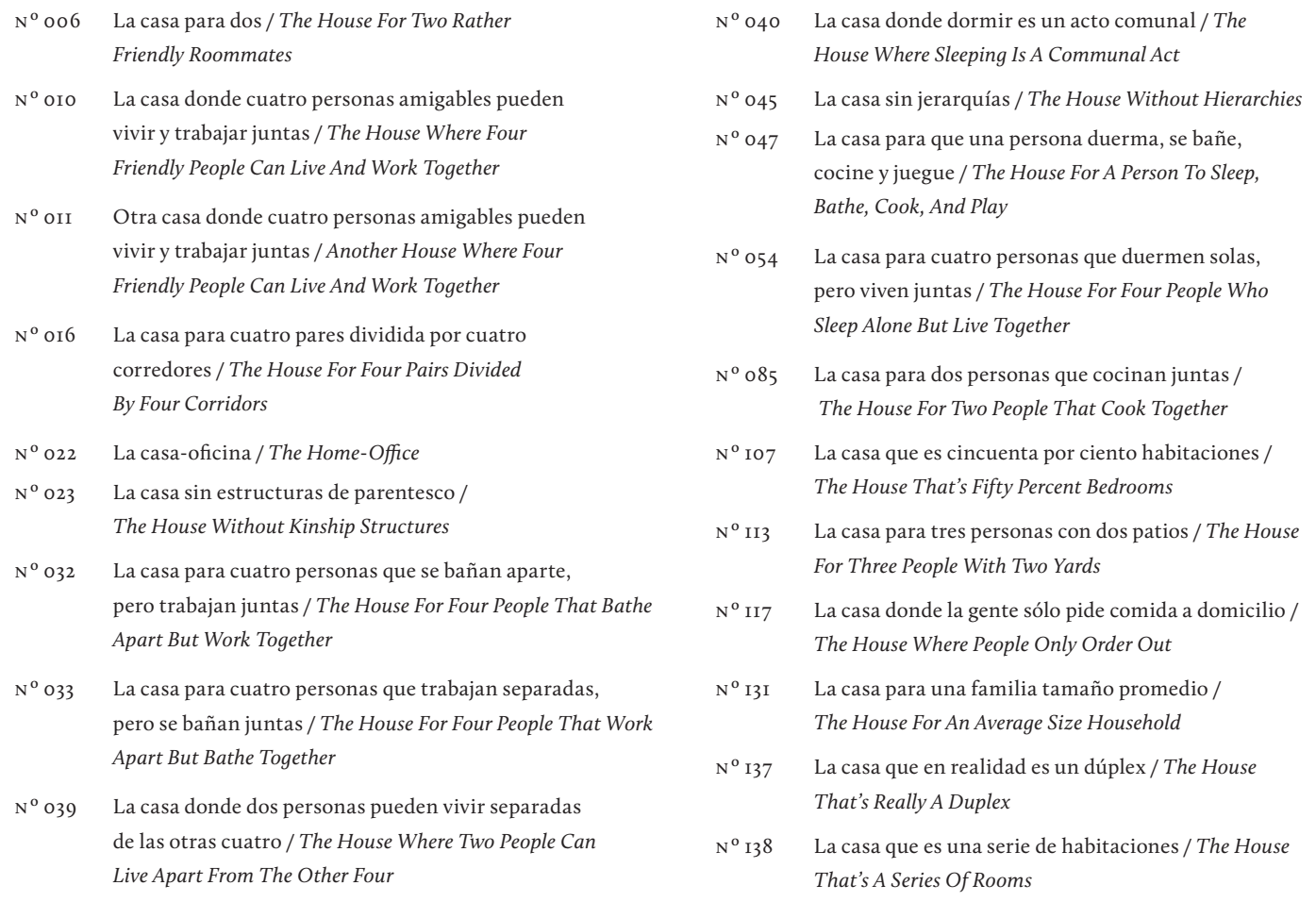

\section{Notas / Notes}

1 ' 138 Model Homes' is the fellowship exhibition by Brittany Utting, the 2017-2018 Willard A. Oberdick Fellow at Taubman College of Architecture and Planning at the University of Michigan.

\section{Bibliografía / Bibliography}

воснner, Mel. «The Serial Attitude», Artforum 6 No. 4 (dic. I967): 28. EAST E R LING, Keller. «Believers \& Cheaters», $\log _{5}$ (Spring/Summer 2005): 34 .

GR A H A M, Dan. «Homes for America», Arts Magazine 4I, 3 (dic. I966 -

en. I967).
SEARS, ROEBUCK, AND CO. «The Cape Cod» [aviso publicitario]. Sears Modern Homes, I934.

SEARS, ROEBUCK, AND CO. «The Milford» [aviso publicitario].

Sears Modern Homes, I935.

TAF U R I, Manfredo. Architecture and Utopia. Boston: The Massachusetts Institute of Technology, I976.

\section{Brittany Utting}

<ubritt@umich.edu>

Architect. Master of Architecture, Yale University, 2014. Bachelor of Science in Architecture, Georgia Institute of Technology, 2011. Director of the design collaborative HOME-OFFICE, she explores how our built environment overlays with economies of labor, leisure, and production. Currently teaches architecture at the University of Michigan, where she is a member of the editorial board of CARTHA Magazine and 20172018 Willard A. Oberdick Fellow. 